j. port. sci. res.
ISSN: 2616-7441 (Online)
ISSN: 2616-622 (Print)
ISSN: 2616-7220 (USB)

\title{
Anthelmintic Activity of Methanolic Extract of Eucalyptus globulus Bark
}

\author{
N. DORA BABU*1, Y, Z. FARID ${ }^{2}$ \\ ${ }^{1 \& 2}$ College of Pharmacy, Uruk University. Baghdad. Iraq.
}

duro@uruk.edu.iq

\begin{abstract}
In the last few years there has been an exponential growth in the field of herbal medicine and these drugs are gaining popularity both in developing and developed countries because of their natural origin and less side effects. Many traditional medicines in use are derived from medicinal plants, minerals and organic matter. The World Health Organization (WHO) has listed 21,000 plants, which are used for medicinal purposes around the world. . The current review focuses on herbal drug preparations and plants used in the treatment of different chronic dieses in the world. The use of Ayurvedic medicines is common in both adults and children and is increasing in many areas of the world. This paper will discuss the benefits with use of herbal medicines as Antipyretic, Antiulcer, Anti-diabetic and Anti-cancerous activity.
\end{abstract}

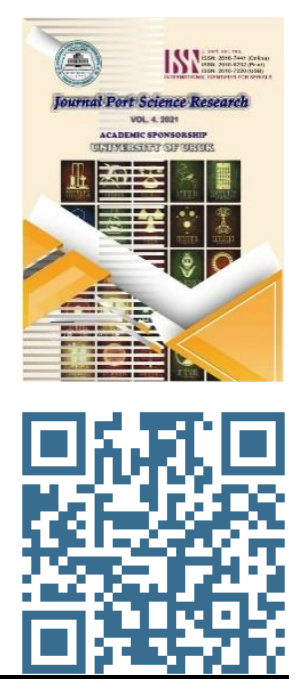

Keywords: Prosopis Farcta, Endogenous, Vitexin, Invitro, IR, UV,MS, and NMR spectrometry

\section{INTRODUCTION}

Medicinal plants and their derivatives are widely used in traditional cultures all over the world and they are becoming increasingly popular in modern society as natural alternatives to synthetic chemicals [1].

In the last few decades there has been an exponential growth in the field of herbal medicine. It is getting popularized in developing and developed countries owing to its natural origin and lesser side effects [2] At the present days, the modern conventional health care is burdened with great problems of unsafe medicines, chronic diseases, resistant infections, auto immune disorders and degenerative disorders of ageing, despite great scientific advances.[3][4] The World Health Organization (WHO) estimated that approximately $80 \%$ of population relies mainly on traditional medicines, mostly plant drugs in their health care.

Today, Ayurveda coexists with modern system of medicine, and is still widely used and practiced. About $30 \%$ of the currently used therapeutics is of natural origin [5]. Eucalyptus globulus, commonly known as southern blue gum [6] or blue gum, is a species of tall, evergreen tree endemic to southeastern Australia. This Eucalyptus species has mostly smooth bark, juvenile Bark that are whitish and waxy on the lower surface, glossy green, lance-shaped adult Bark, glaucous, ribbed flower buds arranged singly or in groups of three or seven in leaf axils, white flowers and woody fruit. There are four subspecies, each with a different distribution across Australia, occurring in New South Wales, Victoria and
Tasmania. The subspecies are the Victorian blue gum, Tasmanian blue gum, Maiden's gum, and Victorian eurabbie.

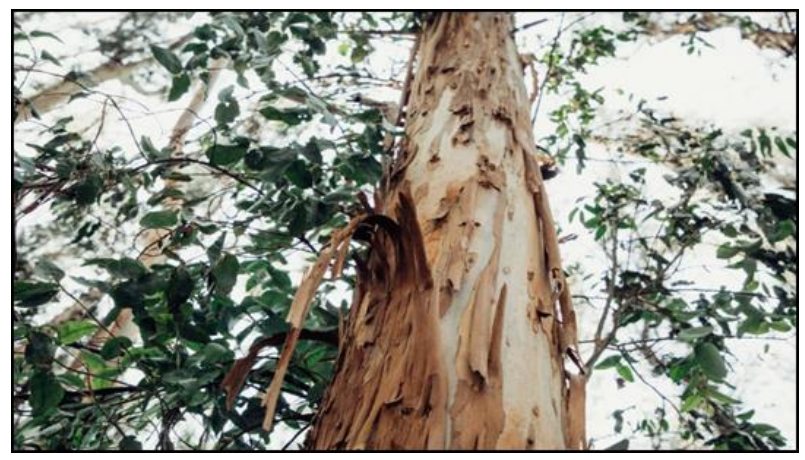

Fig no: 01 whole plant

PLANT PROFILE TAXONOMY Kingdom: Plantae Phylum: Magnoliophyta Class: Magnoliopsida Order: Myrtales Family: Myrtaceae Genus: Eucalyptus Species: E. globulus Subspecies: E. globulus.

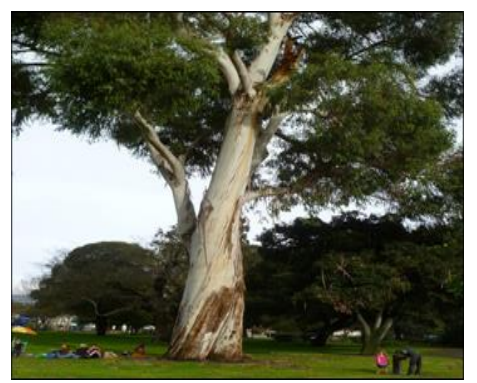

Fig no: 02 bark 


j. port. sci. res.
ISSN: 2616-7441 (Online)
ISSN: 2616-6232 (Print)
ISSN: 2616-7220 (USB)

\subsection{Geographical Distribution}

Globulus is mainly found in lowland parts of Tasmania, but is also found on some Bass Strait islands including King Island, and in the extreme south-west of Victoria. Subspecies maidenii occurs on near-coastal ranges of south-eastern New South Wales and eastern Victoria. Subspecies pseudoglobulus is mostly distributed in eastern Gippsland but there are isolated populations further inland and in the Nadgee Nature Reserve in south-eastern New South Wales[7].

\subsection{Morphology}

\section{Appearance}

Eucalyptus globulus is an aromatic tree. Commonly attains a height of 150-180 ft. (45.7-54.9 m) and a diameter of 4-7 ft. (1.2-2.1 m). It has a straight trunk up to two-thirds of its total height and a well-developed crown.

Foliage. Bark are glossy, dark green, thick and leathery. They average in length from 5.9-7.9 in. $(15-20 \mathrm{~cm})$. The Bark of the young shoots are ovate, opposite, and horizontal. They are covered with a grey, waxy bloom which is much thicker on the bottom surface of the leaf.

Flowers. Solitary white flowers with many stamens, arise from the axils on flattened stalks. They range from 1.6-2.2 in. $(4-5.5 \mathrm{~cm})$ wide. Sepals and petals are united to form a warty lid which is present on the bud and drops off at flowering. Flowers from December to May.

Fruit. The fruit is a hard, woody globose capsule. The fruit is $0.8-1$ in. $(2-2.5 \mathrm{~cm})$ across. The numerous seeds are approximately 0.08 in. $x 0.04$ in. $(2 \times 1 \mathrm{~mm})$. Seeds are dark brown with a brownish red chaff. [8][9[10][

\subsection{Traditional uses of eucalyptus globulus}

In African traditional medicine, an infusion or decoction of the Bark is taken, or applied externally in baths, lotions or enemas, against asthma, bronchitis, tonsillitis, colds, urinary

problems and haemorrhages. The vapour of boiled dried Bark is inhaled against asthma, cough, flu, croup and diphtheria, or fine leaf powder is inhaled. In Sudan a decoction of the Bark is drunk to treat malaria and in Madagascar the Bark are heated and the vapour inhaled against this disease. Powdered or bruised Bark or a leaf decoction are applied on abscesses and wounds.

A paste of powdered Bark is rubbed in against rheumatism. In Kenya a leaf decoction is used in a bath to treat chickenpox in children. In Ethiopia a leaf extract is gargled for treatment of meningitis.

In southern Africa the Bark are used against stomach-ache. Gum resin from the plant is used against diarrhoea. Various leaf preparations are used as insect repellent, and in Kenya the fresh or dried Bark are used for controlling snails[11]

\subsection{Biological and pharmacological action}

During past several years, Eucalyptus globulus is gaining lot of interest according to researchers' point of view. Recently many pharmacological studies have been conducted on Eucalyptus globulus. A summary of the findings of these studies performed is presented below Antibacterial, Antidiabetic, Antiplaque, Antitumor, Antiviral, Antifungal, Antihistaminic, Anti-inflammatory, Antimalarial, Cytochrome p450 enzymes inhibitor Intestinal Fructose Absorption Inhibition, Nerve Blocker[12.[13][

\subsection{PLAN OF WORK}

- Collection of plant material

- Extraction of drug

- Collection of Earth worms

- Phytochemical screening

- Anthelmintic activity

\subsection{Collection of sample:}

The sample of eucalyptus bark was collected from a public garden and then underwent a cleaning process to ensure purity. Afterward, we started cutting the bark into small pieces to undergo extraction.

\section{Preparation of extracts}

After grinding of the bark, 50gm of the final sample was dissolved in $500 \mathrm{ml}$ of a $70 \%$ ethanol solution and then underwent a reflux extraction for 1 hour followed by filtration of the extract using a filter paper. The extract was then concentrated at $80 \mathrm{C}$ for 1 hour to form a semisolid form and then was transferred into sterile wide-mouthed bottles and refrigerated until used.

\section{Phytochemical analysis}

Test for reducing sugars: A little amount of Fehling's reagent was added to the extract and the mixture was boiled for 2 min. A brick red color indicated the presence of glycosides.

Test for proteins: $0.5 \mathrm{ml}$ of each extract was treated with equal volume of $1 \%$ sodium hydroxide to which a few drops of copper sulphate solution was gently added. the solution turning to purple colour indicated the presence of proteins. [10].

Test for steroids: $0.5 \mathrm{ml}$ of extract was dissolved in $3 \mathrm{ml}$ of chloroform and was filtered. To the filtrate, concentrated suphuric acid was added by the sides of the test tube, which formed a lower layer. A reddish brown colour ring with a slight greenish fluorescence was taken as the indication for the presence of steroids. 


\section{Test for amino acids:}

Ninhydrin test: To the sample extract, a few drops of Ninhydrin reagent were added. After mixing it well, the solution was boiled in water for 2-3 minutes. A bluish black colour indicated the presence of proteins.

Table No: 01 +: presence of compounds,: - Absence of compound. Eucalyptus globulus

\begin{tabular}{|c|c|c|}
\hline S.NO & Parameters & Aqueous \\
\hline 1 & Carbohydrates & - \\
\hline 2 & Amino acids & + \\
\hline 3 & Protein & - \\
\hline 4 & Vitamin C & - \\
\hline 5 & Chloride & + \\
\hline 6 & Alkaloids & + \\
\hline 7 & Flavonoids & - \\
\hline 8 & Phenols & + \\
\hline 9 & Tannins & - \\
\hline 10 & Steroids & + \\
\hline 11 & Terpenoids & + \\
\hline 12 & Saponin & \\
\hline & & + \\
\hline
\end{tabular}

Test for glycosides: $1 \mathrm{ml}$ of extract solution was hydrolysed with diluted conc.H2SO4 extracted with benzene. $1 \mathrm{ml}$ of dil.ammonia was added to it. Pink or Red colouration suggested the positive response for anthraquinones.

Test for alkaloids: $0.5 \mathrm{gm}$ of extract was stirred with $2 \mathrm{ml}$ of Mayer's reagent. The cream colour indicates the presence of alkaloids.

Test for lipids: To the extract add $3 \mathrm{ml}$ of alkali $\mathrm{KOH}$ solution and boil it for 10minutes. The formation soap indicates the presence of lipids.

Test for flavonoids: To the extract add few drops of $\mathrm{NaOH}$ the formation of yellow colour takes place which upon addition of acid decolourisation takes place. Which indicates the presence of flavonoids.

Test for fats $\&$ oils: TO the extract add petroleum ether and pass the solution trough filter paper. Formation of oil globules indicates the the presence of fats and oils.

Test for Vitamin C: To $2 \mathrm{ml}$ of $2 \%$ solution add $2 \mathrm{ml}$ of water and $1 \mathrm{gm}$ sodium bi carbonate and $20 \mathrm{mg}$ of ferrous sulphate. Shake and stand. The appearance of violet color indicates the presence of vitamin $\mathrm{C}$.

\section{Phytochemical screening}

\section{Preparation of plant extract:}

The stored plant extracts were redissolved at concentrations of 40,60 , and $100 \mathrm{mg} / \mathrm{ml}$ normal saline solution and used for screening the anthelmintic activity. Standard Albendazole was used with the same concentrations. All the solvents are freshly prepared before the commencement of the experiment.

\section{Animals}

Adult Iraqis earthworms, Pheretima posthuma resemble the intestinal round worm parasites of human beings both anatomically and physiologically and hence were used to study the anthelmintic activity. Healthy adult Indian earthworms Pheritima posthuma were used for evaluating the anthelmintic activity. All healthy earthworms were of approximately $5-7 \mathrm{cms}$ in size and $0.1-0.2 \mathrm{~cm}$ in width. They were collected from local place, washed and kept in water until they were used for screening of activity.

\subsection{Anthelmentic activity}

\subsection{Introduction Of Worms Types Of Worm}

\section{Flatworms}

\section{ROUNDWORMS}

\section{SEGMENTED WORMS}

There are about one million species of worm, living in a wide range of habitats. They have a long, thin body, and have no legs. Many worms are parasites that live on or in another animal and use strong mouthparts to feed off that animal. Others are predators, and can move quite quickly. The three main groups are FLATWORMS, ROUNDWORMS, and SEGMENTED WORMS.

\section{Types of worms}

There are many different phyla of worms. The following three are the best-known. Some worms live on land in burrows, feeding on plant matter;

others live in the sea or fresh water, filtering food from water.

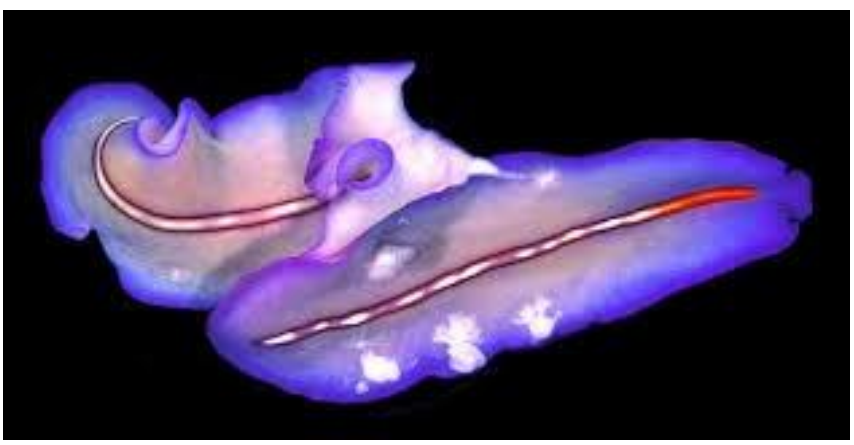

Phylum: Platyhelminthes 


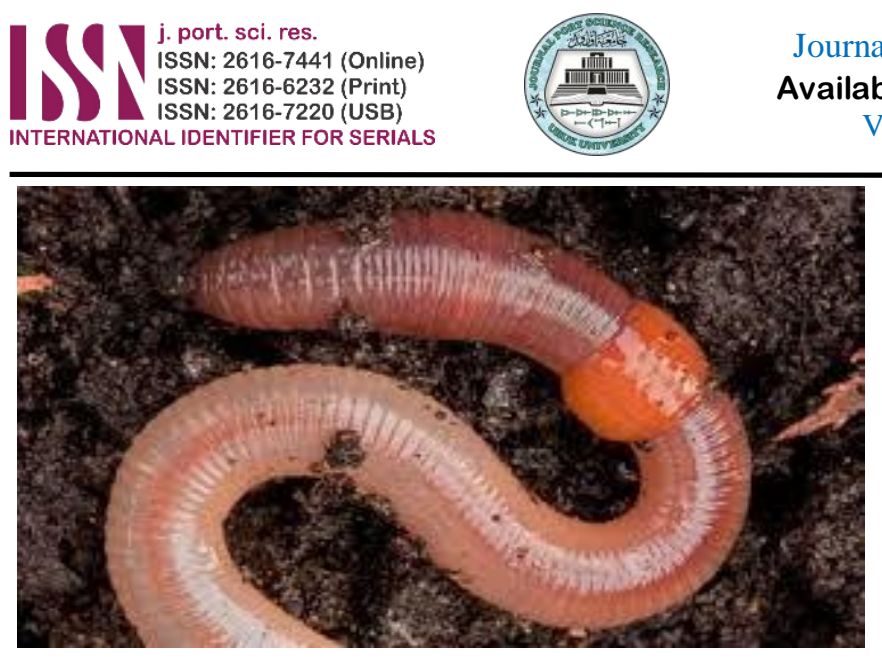

Fig No: 03 Flatwor

Features: about 20,000 species flat, unsegmented bodies, with a mouth but no anus, many live in water.

\section{Phylum: Nematoda Roundworms}

Features: about 25,000 species unsegmented bodies, gut with mouth and anus FLATWORMS: There are about 20,000 species of flatworm. They have a solid, flat body that does not contain blood. Most flatworms are parasitic, but some are free-living.

\section{Marine flatworm}

Marine flatworms absorb oxygen through the surface of their very thin, flattened body. They creep along, rippling their body to help them move. Eyespots enable them to find their way around. Most are predators, eating tiny animals with the mouth situated on the underside of their body.

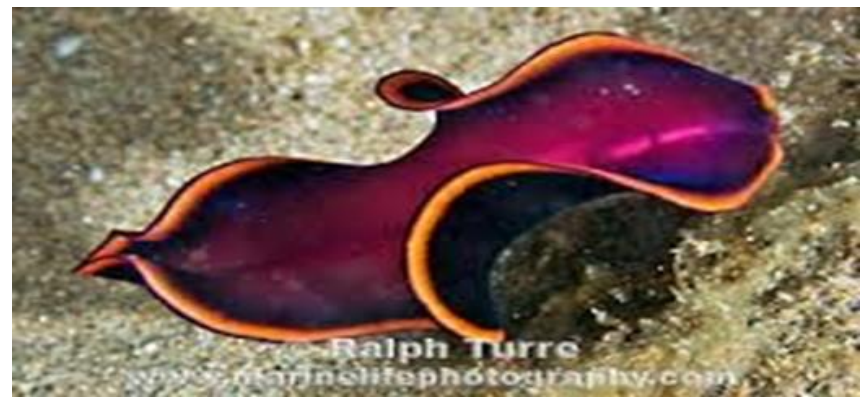

Fig no: 05 marine flatworm

\section{Tapeworm}

Tapeworms are parasites that live in other animals, including humans. They have hooks and suckers on their head to attach themselves to the animal's gut wall. They have no digestive system but absorb food through the surface of their body. They are hermaphrodites - they produce both eggs and sperm.
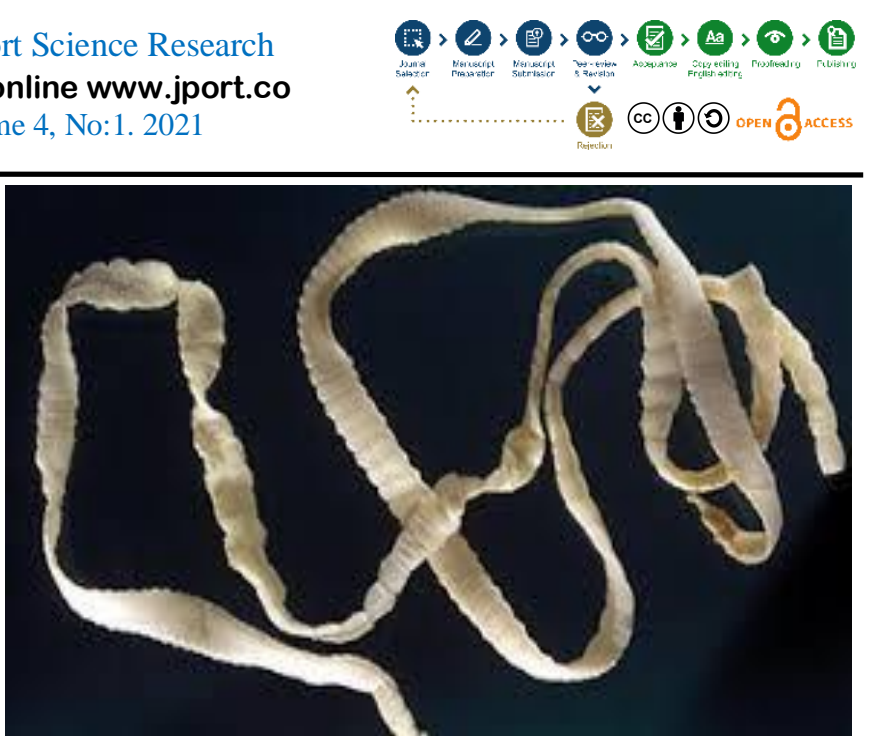

Fig no: 06 tapeworm

\section{Roundworms}

Roundworms, or nematodes, are found almost anywhere and exist in huge numbers. As many of the roundworms are transparent, few people are aware of them. The roundworm has a long, round body that tapers towards the tail. The outer layer, or cuticle, is smooth. Muscles run along its body, but not around it. To move along, the worm contracts these muscles, thrashing backwards and forwards in a single plane, making $\mathrm{C}$ or $\mathrm{S}$ shapes.

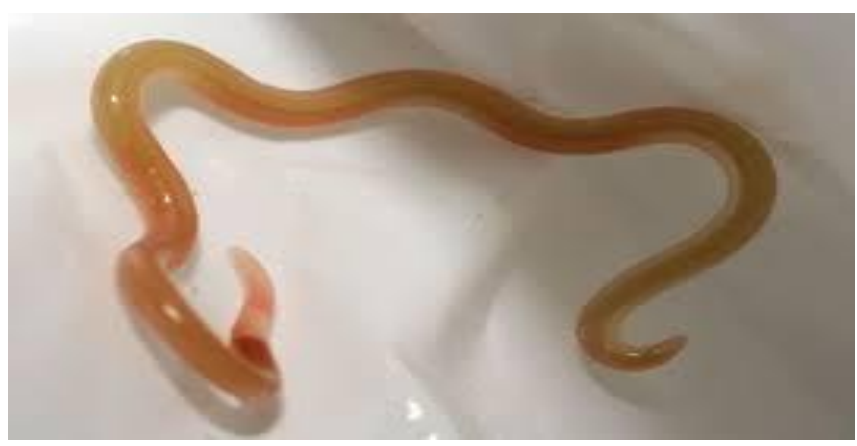

Fig No: 07 ROUNDWORMS

The roundworm has a long, round body that tapers towards the tail. The outer layer, or cuticle, is smooth. Muscles run along its body, but not around it. To move along, the worm contracts these muscles, thrashing backwards and forwards in a single plane, making $\mathrm{C}$ or $\mathrm{S}$ shapes.

\section{Earthworm}

Earthworms are formed from many segments. Only the gut runs through the whole body from head to tail. Worms have a circulatory system with blood vessels but no heart. The thickened area towards the front of their body secretes mucus, which binds mating worms together and forms a cocoon for eggs. 


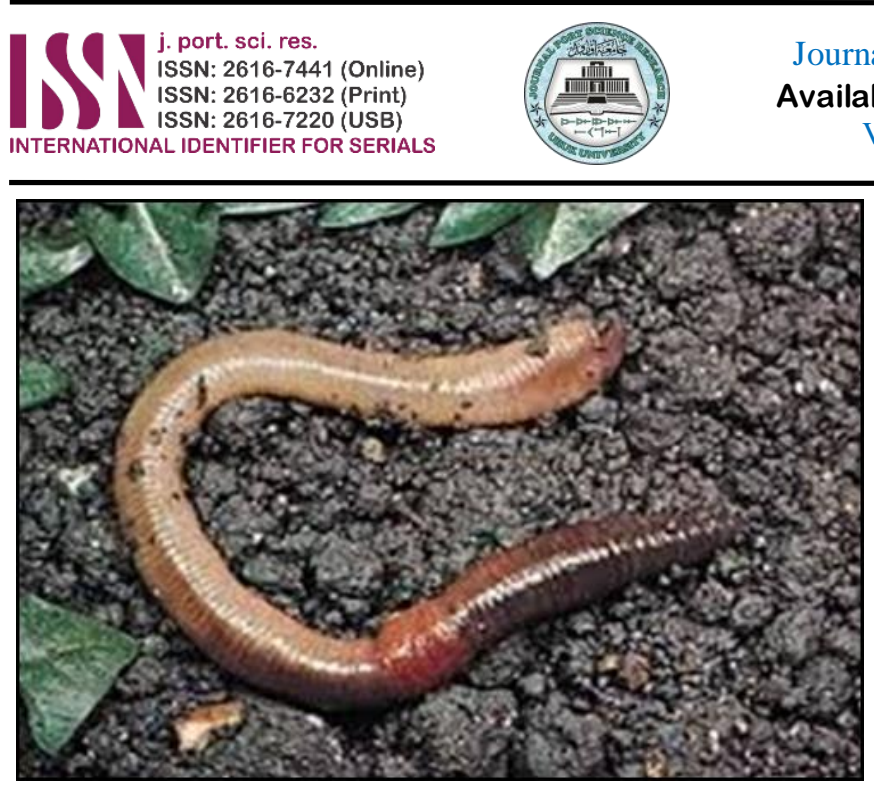

Fig no: 08 earthworm

\section{Leech}

Leeches are parasites that live on the outside of other animals. They have specialized cutting jaws to bite through skin so that they can suck the animal's blood. Substances in their saliva prevent the blood from clotting and make the bite painless so that the animal is unaware it has been bitten. Leeches move by shifting one sucker forwards and then bringing the other one up behind it.

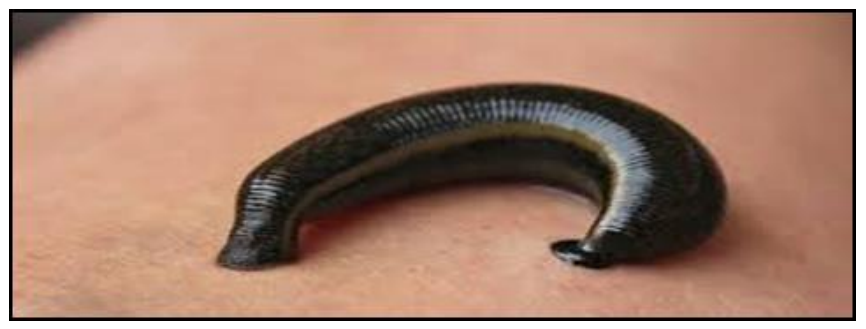

Fig no: 09 leech

Pheretima is a genus of earthworms found mostly in New Guinea and parts of Southeast Asia. Species belonging to the genus Pheretima have a clitellum, which is a band of glandular tissue present on segments 14 to 16. Individuals are hermaphroditic and reproduction can be either sexual or parthenogenetic. Female genital pores lie on the ventral surface of segment

14.A pair of male genital pores is situated ventrally on segment 18 . Genital papiliae may also be present ventrally. As with all earthworms, development of young is without a larval stage and takes place in cocoons.

Pheretima are generally nocturnal, like most earthworms, and have an aversion to light. They come out only at night, and feed and reproduce only at night. Also, similar most earthworms, they must keep their body surface wet to respire.

Similar genera include Amynthas, Archipheretima, Duplodicodrilus, Metaphire, Metapheretima, Pithemera, and Polypheretima. In combination these "pheretimoid" genera have about 1,000 species, making them an important ecological and taxonomic group of Oriental species (cf. Lumbricidae from Eurasia; Moniligastridae from Indo-Asian region).

Pheretima worms are administered as a medicine in China. The worm contains biological agents beneficial in rat models of stroke. In clinical practice, it has been recognized for its curative effects in the treatment of epilepsy.[2] It contains hypoxanthine, lumbrofebrin, and lumbritin.

\subsubsection{Phytochemical screening:}

Preliminary phytochemical screening of the aqueous extract of eucalyptus bark reveals the presence of Amino acids, Flavonoids and Terpenoids. Different doses of the extracts were screened for their activity mainly due to the presence of flavonoids respectively.

Table no: 02

\begin{tabular}{|c|c|}
\hline Name of Phytoconstituents & - \\
\hline Alkaloids & - \\
\hline Carbohydrates & + \\
\hline Amino acids & + \\
\hline Tannins & - \\
\hline Steroids & - \\
\hline Saponins & + \\
\hline Flavanoids & - \\
\hline Glycosides & - \\
\hline Mucilages & + \\
\hline Terpenoids & \\
\hline
\end{tabular}

Anthelmintic activity related photos

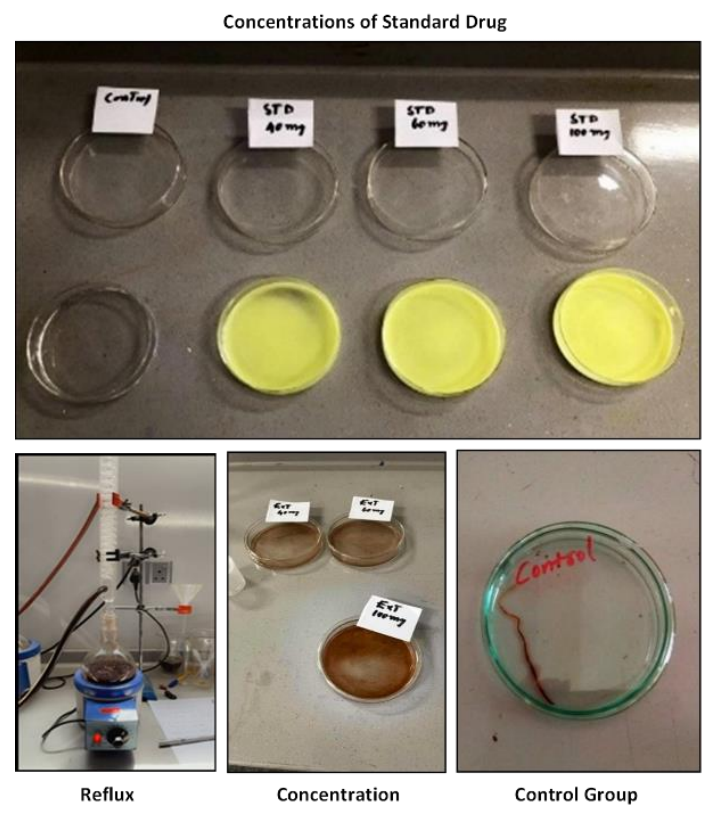

Al-Jeboory, A., Ismail, A. and Al-mgother, B., (2021). Vitexin Anew Antihypertensive Drug. Journal port Science Research, 4(1), pp.11-16. https://doi.org/10.36371/port.2021.3 


j. port. sci. res.
ISSN: 2616-7441 (Online)
ISSN: 2616-6232 (Print)
ISSN: 2616-7220 (USB)

\section{CONCLUSION}

Aqueous extract has significant anthelmintic activity when compared to standard Albendazole. The paralysis and death time of aqueous extract was 24,20,14 and 28,24,18 minutes respectively at concentrations 40,60 and $100 \mathrm{mg} / \mathrm{ml}$ for the eucalyptus extract and these are 22,18, 12 and 24, 20,14 minutes respectively at concentrations 40,60 and $100 \mathrm{mg} / \mathrm{ml}$ for Albendazole.

The plant Eucalyptus bark was collected from a public garden. The bark of the plant was subjected to reflux extraby using ethanol as a solvent. Then this extraction distilled to get a concentrated mass. Phytochemical investigation was done.

The work states that the presence of Flavonoids, Terpenoids, Amino acids and Tannins in the extract of Eucalyptus bark was responsible for its anthelmintic activity. Aqueous extract was shown significant values with respective to paralysis and death time of earth worms. It is interesting to observe the results of anthelmintic effect of aqueous extract. But further investigations on the isolation of active compounds present in the extracts and in vivo studies are necessary to identify a potential chemical entity for clinical use.

\section{REFERENCES}

[1] Silva-Pando, F., \& Pino-Pérez, R. (2016). Introduction of Eucalyptus into Europe. Australian Forestry, 79(4), $283-291$. https://doi.org/10.1080/00049158.2016.1242369

[2] Costa, J., Vaillancourt, R. E., Steane, D. A., Jones, R. C., \& Marques, C. (2017). Microsatellite analysis of population structure in Eucalyptus globulus. Genome, 60(9), 770-777. https://doi.org/10.1139/gen-2016-0218

[3] Munz, P. A. (1968). A California Flora and Supplement. A California Flora and Supplement. University of California Press. https://doi.org/10.1525/9780520317598

[4] Drury, C. (1921, January 29). Chippendale. Notes and Queries. https://doi.org/10.1093/nq/s12-VIII.146.90-i

[5] Missingham, R. (2008). Access to Australian Government information: A decade of change 1997-2007. Government Information Quarterly, 25(1), 25-37. https://doi.org/10.1016/j.giq.2007.07.001

[6] Guanoluisa, J. (2019). Efecto inhibitorio del aceite esencial de eucalyptus globulus l. (eucalipto) vs gluconato de clorhexidina sobre cepas de aggregatibacter actinomycetemcomitans. Estudio in vitro. Universidad Central del Ecuador.

[7] Bolza, E., Keating, W. G., (1972). African timbers - the properties, uses and characteristics of 700 species., 710 pp.Melbourne, Division of Building Research, CSIRO., Australia. English language.

[8] Sastri, B. (1950). The Wealth of India, A Dictionary of Raw Material and Industrial Products. Publication and Information Directorate (CSIR New Delhi), 120-121.

[9] Council of Scientific \& Industrial Research (CSIR). (2019). In The Grants Register 2019 (pp. 259-259). Palgrave Macmillan UK. https://doi.org/10.1007/978-1-349-95810-8_370

[10] Neve J et al.: Sideroxylonal C: A new inhibitor of human plasminogen activator inhibitor type-1, from the flowers of Eucalyptus albens. Nat. Prod. 1999; 62: 324-326.

[11]Patil, N. P., Bhapkar, P. H., Maheshwari, K. M., Jagtap, P. N., Shewale, A. P., \& Patil, R. Y. (2014). Anthelmintic activity of aqueous extracts of the Alpinia galangal Willd. Rhizomes. International Journal of Pharmaceutical Sciences Review and Research, 25(2), 72-75.

[12] Patil, N. P., Bhapkar, P. H., Maheshwari, K. M., Jagtap, P. N., Shewale, A. P., \& Patil, R. Y. (2014). Anthelmintic activity of aqueous extracts of the Alpinia galangal Willd. Rhizomes. International Journal of Pharmaceutical Sciences Review and Research, 25(2), 72-75. 